\title{
Medical History Dictionary
}

National Cancer Institute

\section{Source}

National Cancer Institute. Medical History Dictionary. NCI Thesaurus. Code C49702.

A reference source that provides meanings of words related to medical history. 